\title{
Growth of Cupania vernalis seedlings produced under different substrates
}

\section{Crescimento de mudas de Cupania vernalis produzidas em diferentes substratos}

\author{
Michele Fernanda BORTOLINI ${ }^{1}$; Henrique Soares KOEHLER ${ }^{2}$; Katia Christina ZUFFELLATO-RIBAS ${ }^{3}$; \\ Andréa Maria Teixeira FORTES ${ }^{4}$ \\ ${ }^{1}$ Autor para la correspondencia - Bióloga, Dra. Escola de Saúde e Biociências, Pontifícia Universidade Católica do Paraná, \\ Av. da União, 500, Jardim Coopagro, Toledo - Pr, CEP 85902-532, michele.bortolini@pucpr.com \\ 2 Eng. Florestal, Dr., Depto. Fitotecnia e Fitossanitarismo, Setor de Ciências Agrárias, Universidade Federal do Paraná \\ (UFPR).koehler@ufpr.br \\ ${ }^{3}$ Bióloga, Dra., Depto. Botânica, Setor de Ciências Biológicas, Universidade Federal do Paraná (UFPR), Centro Politécnico, \\ UFPR.kazu@ufpr.br \\ ${ }^{4}$ Bióloga, Dra., Setor de Ciências Biológicas e da Saúde, Universidade Estadual do Oeste do Paraná (UNIOESTE). \\ amtfortes@unioeste.br
}

Recebido em: 12-12-2013; Aceito em: 29-05-2016

\begin{abstract}
Cupania vernalis (camboatá), it can be used in carpentry and landscaping, as well as for mixed plantings used for restoration of degraded areas. The objective was to evaluate the effect of different substrates, over time, in growth of Cupania vernalis seedlings. The experiment was conducted in nursery in the municipality of Santa

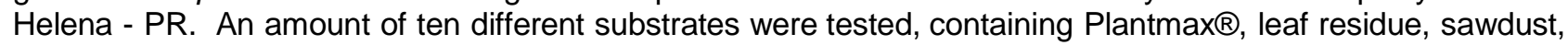
broiler litter, bovine manure and carbonized rice husk, in a completely randomized design with five replications of twelve seedlings in split-plots design. For 210 days, height and stem diameter were evaluated, dry mass of roots and shoots were also determined as well as its relationship between and the leaf area for ten seedlings of each substrate. Furthermore, water retention capacity and total porosity of substrates were determined. The most of substrates provided gradual increase in diameter and height of seedlings. Substrates with Plantmax ${ }^{\circledR}+$ sawdust + bovine manure and substrate with Plantmax ${ }^{\circledR}+$ carbonized rice husk + bovine manure, presented, respectively, the best results for diameter $(2.0 \mathrm{~mm}$ and $1.9 \mathrm{~mm})$ and height $(4.5 \mathrm{~cm}$ and $4.6 \mathrm{~cm})$, as well as root dry mass $(0.29 \mathrm{~g}$ and $0.21 \mathrm{~g})$ and dry mass of shoots $(0.58 \mathrm{~g}$ and $0.47 \mathrm{~g})$.
\end{abstract}

Additional keywords: camboatá; native species; seedling production.

\begin{abstract}
Resumo
Cupania vernalis (camboatá) pode ser utilizada na marcenaria e no paisagismo, além de ser indicada para plantios mistos destinados à recomposição de áreas degradadas. O objetivo foi avaliar o efeito de diferentes substratos, ao longo do tempo, no crescimento das mudas de Cupania vernalis. O experimento foi realizado em viveiro no município de Santa Helena - PR. Foram testados dez diferentes substratos, contendo Plantmax $\AA$, resíduo de folha, serragem, cama de aviário, esterco bovino e casca de arroz carbonizada, em delineamento inteiramente casualizado, com cinco repetições de doze mudas, em esquema de parcelas subdivididas no tempo. Durante 210 dias, foram avaliadas altura e diâmetro do colo, e determinada a massa seca das raízes e da parte aérea, a relação entre estas e a área foliar, para dez mudas, de cada substrato. Determinaram-se também a capacidade de retenção de água e a porosidade total dos substratos. A maioria dos substratos proporcionou aumento gradativo no diâmetro e na altura das mudas. Os substratos com Plantmax ${ }^{\circledR}$ + serragem + esterco bovino e o substrato com Plantmax ${ }^{\circledR}$ + casca de arroz carbonizada + esterco bovino apresentaram, respectivamente, os melhores resultados para diâmetro $(2,0$ e 1,9 mm) e para altura $(4,5$ e 4,6 cm), assim como para a massa seca da raiz $(0,29$ e 0,21 g) e massa seca da parte aérea $(0,58$ e $0,47 g)$.
\end{abstract}

Palavras-chave adicionais: camboatá; espécie nativa; produção de mudas.

\section{Introduction}

Cupania vernalis Cambess (Sapindaceae), popularly known as camboatá, camboatá-vermelho, occurs in Bolivia, Paraguay, Argentina, Uruguay and Brazil, and it is indicated for landscaping in parks, squares and streets, in addition to wood use (Lorenzi, 2000), the bark has medicinal properties against bron- chitis, asthma, and is also antipyretic and antiseptic (Backes \& Irgang, 2002).

Another purpose given to $C$. vernalis, is its use to mixed plantings for the recovery of degraded areas of permanent preservation, considered as a secondary species adapted to direct sunlight and producer of fruits sought by birds, in addition for presenting honey flowers (Lorenzi, 2000). 
Plantings with the purpose of recovering degraded ecosystems, restoration of riparian forests and replacement of legal reserve, reflect the concern for environmental issues derived from devastation of forests (Fowler, 2000), activity that demands services and products, in particular the production of seedlings of forest species (José et al., 2005). However, the exact information about proper procedures are still scarce in seedling production of native tree species (Carvalho, 2000), thus inhibiting the use of these in reforestation programs and large-scale production.

To produce seedlings selected with proper development characteristics, aiming at ensuring success in the production of future forestry, numerous studies have been developed in order to control and to obtain good quality seedlings, able to withstand the environmental adversities after planting, and also with low cost (Souza et al., 2005).

Seedlings of good quality should be vigorous, with leaves with size and coloring typical of species and still in good nutritional status. However, the quality standards vary between species and for the same species at different ecological sites. The determination of seedling quality is based on the analysis of its physiological and morphological characteristics (Carneiro, 1995).

One of the most important factors in the formation of seedlings with quality is the substrate, which aims at ensuring plant development in a short period of time, with features that promote the availability of nutrients and moisture retention, in order to meet seedling needs (Cunha et al., 2006).

When choosing the substrate to be used, Toledo (1992) recommends evaluation of the availability of materials, its physical and chemical characteristics, its weight and cost on formulation. The ideal solution it would use substrates of materials readily available in planting region, facilitating the reduction of expenses (Silveira, et al. 2002). The use of organic waste from urban, industrial or agricultural origin, it would be an alternative for economically viable and environmentally acceptable materials (Maeda et al., 2007), but as it is difficult to find a single material that correspond to all the requirements of cultivated species, it is possible to combine different types of materials (Wendling et al., 2002). Substrates containing in its composition proportions of organic compounds have shown good results, since it can contribute to the aeration, porosity, water absorption and other factors in the final mixture of substrate (Costa et al., 2012).

As studies on appropriate procedures in production of native essence are necessary and, given species importance, this study aimed at evaluating the effect of different substrates, over time, in growth of Cupania vernalis seedlings.

\section{Material and methods}

Seeds of Cupania vernalis (camboatá), were collected in December 2007 from mother trees with more than $60 \mathrm{~cm}$ in diameter at breast height, in the municipality of Santa Helena - PR, latitude 24\%51'37" south and longitude 5419'58" west, average altitude of 258 meters above sea level, with humid subtropical climate (IBGE, 2009).

After the removal of seed aryl, according to instructions of Guimarães Junior \& Cogni (2002), seeds were submitted to chemical scarification by immersion for $5 \mathrm{~min}$ in sulfuric acid followed by washing on running water, with preliminary tests in order to overcome dormancy of species.

The installation of the experiment occurred in the nursery of the Experimental Stations of the Universidade Estadual do Oeste do Paraná UNIOESTE in Santa Helena - PR in December 2007. The sowing was performed in polypropylene tubes of $200 \mathrm{~cm}^{3}$ at a depth of approximately two times seed diameter, using two seeds in each. After emergence, thinning was carried out leaving one seedling per tube. The tubes were placed on bench, covered with canvas with $60 \%$ shade, under sprinkler irrigation system, triggered twice daily for $15 \mathrm{~min}$ in the late morning and late afternoon, corresponding to approximately to $0.66 \mathrm{~L} \mathrm{~m}^{-2}$ for each sprinkler.

The tested substrates and its respective costs are shown in Table 1. The value of purchase or production of the components of mixtures used as substrate, was passed over by suppliers in the municipality of Santa Helena - PR. The sawdust, broiler litter and bovine manure components were previously semi decomposed, remaining under natural aeration conditions for three months prior its use.

Every month, during 210 days after sowing, evaluations were performed considering height of shoots of seedlings and stem diameter, in the early 60 days after sowing, considering seedlings with a couple of leaves developed in order to be submitted to evaluation. For these variables data were analyzed according to a randomized block design (five replications with 12 seedlings per experimental unit, for each one of the 10 treatments) in a split-plots design (six evaluations during 210 days).

The dry mass of roots and shoots, ratio of dry mass roots by dry mass of shoots and leaf area, according to the leaf disk method adapted from Benincasa (1988), were evaluated at the experiment after 210 days-. In this case, a total of 10 seedlings per treatment were used, randomly assigned. The analysis was performed in a completely randomized design, where each seedling was considered a replication. All data were subjected to analysis of variance, and means compared by Tukey test.

The total quantification of macro and micronutrients of each substrate tested were performed with samples from the moment of installation and after the removal of seedlings at the end of the experiment, as well as vegetable samples from destructive evaluation. These analyzes were carried out by the Agricultural and Environmental Chemistry Laboratory of Unioeste, Marechal Cândido Rondon - PR Campus. The total N and $P$ contents were extracted by sulfuric acid digestion and determination of $\mathrm{N}$ by Kjeldahl distillation 
(Bremner, 1965) and $P$ through UV- Vis (420nm). For $\mathrm{K}, \mathrm{Ca}, \mathrm{Mg}, \mathrm{Cu}, \mathrm{Zn}, \mathrm{Mn}$ and $\mathrm{Fe}$, the extraction was by nitric-perchloric digestion (Johnson \& Ulrich, 1959), and the determination by atomic absorption spectrometry, flame mode.

The water retention capacity (WRC) and total porosity (TP) of substrates were determined on Soils
Laboratory of Embrapa Floresta, Colombo - PR, according to Brasil (2006). These data were analyzed in a completely randomized design, with three replications for each analyzed substrate subjected to analysis of variance and means compared by Tukey test at $5 \%$ probability.

Table 1 - Composition of substrates used for growth of Cupania vernalis (base volume/volume).

\begin{tabular}{|c|c|c|c|c|c|c|c|}
\hline Substrate & $P$ & DLR & SE & $\mathrm{BL}$ & BM & $\mathrm{CRH}$ & Cost $/ m^{3}(R \$)^{*}$ \\
\hline $\mathrm{S}_{1}$ & $100 \%$ & & & & & & 82.08 \\
\hline $\mathrm{S}_{2}$ & $70 \%$ & $30 \%$ & & & & & 57.45 \\
\hline $\mathrm{S}_{3}$ & $60 \%$ & $20 \%$ & $20 \%$ & & & & 49.27 \\
\hline $\mathrm{S}_{4}$ & $60 \%$ & & $30 \%$ & $10 \%$ & & & 49.28 \\
\hline $\mathrm{S}_{5}$ & $60 \%$ & & $40 \%$ & & & & 49.27 \\
\hline $\mathrm{S}_{6}$ & $50 \%$ & & $20 \%$ & & $30 \%$ & & 41.68 \\
\hline $\mathrm{S}_{7}$ & $50 \%$ & $10 \%$ & $20 \%$ & & $20 \%$ & & 41.43 \\
\hline $\mathrm{S}_{8}$ & $50 \%$ & $10 \%$ & $30 \%$ & $10 \%$ & & & 41.08 \\
\hline $\mathrm{S}_{9}$ & $50 \%$ & & & & $30 \%$ & $20 \%$ & 41.68 \\
\hline$S_{10}$ & $50 \%$ & $10 \%$ & & & $20 \%$ & $20 \%$ & 41.43 \\
\hline
\end{tabular}

$\mathrm{P}=$ Plantmax ${ }^{\circledR} ; \mathrm{DLR}=$ decomposed leaf residue,result of urban pruning; SE = sawdust; $\mathrm{BL}=$ broiler litter; BM = bovine manure; $A C=$ carbonized rice husk. ${ }^{*}$ Total cost of purchase or production of mixtures.

\section{Results and discussion}

Mixtures of tested components as a substrate for $C$. vernalis seedlings showed significant interaction with different assessment period for stem diameter and height of seedlings variables. Data for $S_{5}$ were not exposed due to any germination on this substrate.

At 120 days after sowing, it was recorded a sig- nificant difference between the different substrates, with the lowest average for stem diameter of seedlings, registered to $S_{7}(0.97 \mathrm{~mm})$ which differed from $S_{6}, S_{8}$, $S_{9}$ and $S_{10}$ (Table 2). At the end of the experiment, after 210 days, $S_{2}, S_{6}, S_{9}$ and $S_{10}$, resulted in seedlings with greater stem diameter did not significantly differ from each other, with values ranging from 1.92 to $2.01 \mathrm{~mm}$.

Table 2 - Diameter of the stem $(\mathrm{mm})$ of Cupania vernalis seedlings cultivated under different substrates at different ages.

\begin{tabular}{|c|c|c|c|c|c|c|}
\hline \multirow{2}{*}{ Substrate } & \multicolumn{6}{|c|}{ Seedling age (days) } \\
\hline & 60 & 90 & 120 & 150 & 180 & 210 \\
\hline $\mathrm{S}_{1}$ & 1.13Aab & $1.11 \mathrm{Aa}$ & 1.22ABab & 1.40ABCab & 1.47ABCa & 1.37CDab \\
\hline $\mathrm{S}_{2}$ & $0.98 \mathrm{Ad}$ & 1.05Acd & 1.32ABcd & 1.38ABCbc & 1.72Aab & 1.94ABa \\
\hline $\mathrm{S}_{3}$ & $0.90 \mathrm{Aab}$ & $0.81 \mathrm{Ab}$ & 1.08ABab & 1.15BCab & 1.15Cab & 1.25CDa \\
\hline $\mathrm{S}_{4}$ & $0.87 \mathrm{Ac}$ & $0.95 \mathrm{Abc}$ & 1.29ABab & 1.30BCab & $1.50 \mathrm{ABCa}$ & 1.60BCa \\
\hline $\mathrm{S}_{5}$ & - & - & - & - & - & - \\
\hline $\mathrm{S}_{6}$ & 0.95Ad & 1.18Acd & 1.37Abc & $1.54 \mathrm{ABbc}$ & 1.71Aab & $2.01 \mathrm{Aa}$ \\
\hline $\mathrm{S}_{7}$ & $0.81 A c$ & $0.92 \mathrm{Abc}$ & $0.97 \mathrm{Bbc}$ & $1.01 \mathrm{Cabc}$ & 1.24BCab & 1.35CDa \\
\hline $\mathrm{S}_{8}$ & $0.93 \mathrm{Aa}$ & $0.98 \mathrm{Aa}$ & 1.18Aba & 1.19BCa & $1.21 \mathrm{Ca}$ & 1.14Da \\
\hline $\mathrm{S}_{9}$ & $0.89 A c$ & $1.01 \mathrm{Ac}$ & $1.11 \mathrm{Abc}$ & 1.48ABb & 1.63ABab & $1.92 \mathrm{Aba}$ \\
\hline$S_{10}$ & 1.09Acd & 1.03Ad & 1.41Abc & 1.71Aab & 1.72Aab & 2.07Aa \\
\hline Mean & 0.95 & 1.00 & 1.22 & 2.03 & 1.48 & 1.63 \\
\hline \multicolumn{7}{|c|}{ Coefficient of variation: $\quad 15.33 \%$} \\
\hline \multicolumn{7}{|c|}{ 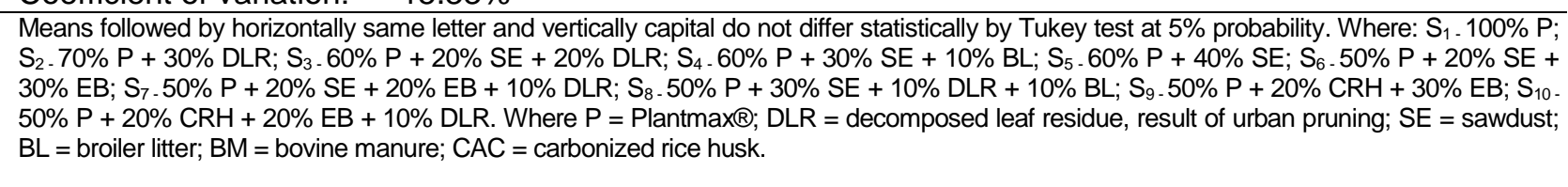 } \\
\hline \multicolumn{4}{|c|}{$\begin{array}{l}\text { In Table } 2 \text { is also possible to observe the grad- } \\
\text { ual increase in stem diameter of seedlings over time } \\
\text { and seedlings in } S_{1}, S_{3} \text { and } S_{8} \text { showed no significant } \\
\text { difference for this variable. The progressive increase in } \\
\text { stem diameter of seedlings may serve as an indication }\end{array}$} & \multicolumn{3}{|c|}{$\begin{array}{l}\text { of the full growth of these, as this feature is recognized } \\
\text { as one of the best indicatives of total seedling quality } \\
\text { (Carneiro, 1995), with crucial importance in the evalua- } \\
\text { tion of seedling potential to survive in field (Souza et } \\
\text { al., 2006). }\end{array}$} \\
\hline
\end{tabular}


When results for height of $C$. vernalis seedlings were analyzed the, it can be seen an increasing over evaluations for all tested substrates, except for $S_{1}$ $(100 \%$ Plantmax $®)$ (Table 3). It is also noted that at 60 days there was significant difference between the substrates, when seedlings produced in $S_{3}(1.45 \mathrm{~cm})$ differed from $\mathrm{S}_{2}$ and $\mathrm{S}_{4}(2.18$ and $1.76 \mathrm{~cm}$, respectively). The lower height obtained for seedlings in $S_{3}$ maintained until the end of the evaluations, result probably justified by the presence of decomposed leaf residue in its composition.

The use of decomposed leaf residue may not have been effective in the height of $C$. vernalis seedlings, but the use of such materials, in addition ecofriendly, it can show good results for other species or in other mixtures, as verified by Barrata Junior (2007).

At the end of evaluations (210 days), the highest were recorded in $S_{6}, S_{9}$ and $S_{10}(4.56,4.61$ and $3.83 \mathrm{~cm}$, respectively), which did not significantly differ from each other. These substrates contain as composition almost the same proportion of commercial substrate and bovine manure (Table 3 ).

The presence of bovine manure on substrates used in the production of forest essences has been efficient in the development of seedlings. Bortolini et al. (2012) obtained better results for sucará seedlings (Gleditschia amorphoides), with substrates containing bovine manure in its formulation. Seedlings of aroeira (Schinus terebinthefolius), eucalyptus(Eucalyptus grandis) and pink cedar (Cedrela fissilis) had also better development when produced on substrates containing bovine manure (Oliveira et al., 2008), similar behavior to those observed in Cupania vernalis seedlings.

Table 3 - Height (cm) of Cupania vernalis. seedlings cultivated in different substrates at different ages.

\begin{tabular}{lllllll}
\hline \multirow{2}{*}{ Substrate } & \multicolumn{7}{c}{ Seedling age (days) } \\
\cline { 2 - 7 } & \multicolumn{1}{c}{60} & \multicolumn{1}{c}{90} & \multicolumn{1}{c}{120} & \multicolumn{1}{c}{150} & \multicolumn{1}{c}{100} \\
\hline $\mathrm{S}_{1}$ & $1.99 \mathrm{ABab}$ & $1.83 \mathrm{ABb}$ & $2.31 \mathrm{ABab}$ & $2.31 \mathrm{BCab}$ & $2.39 \mathrm{EFab}$ & $2.50 \mathrm{Ea}$ \\
$\mathrm{S}_{2}$ & $2.18 \mathrm{Ad}$ & $2.05 \mathrm{ABd}$ & $2.48 \mathrm{ABcd}$ & $2.86 \mathrm{ABCbc}$ & $3.42 \mathrm{BCDab}$ & $3.74 \mathrm{Ca}$ \\
$\mathrm{S}_{3}$ & $1.45 \mathrm{Bc}$ & $1.62 \mathrm{Bbc}$ & $2.05 \mathrm{Babc}$ & $2.18 \mathrm{Cab}$ & $2.04 \mathrm{Fabc}$ & $2.48 \mathrm{Ea}$ \\
$\mathrm{S}_{4}$ & $1.76 \mathrm{Ad}$ & $2.21 \mathrm{ABbc}$ & $2.58 \mathrm{ABab}$ & $2.87 \mathrm{ABCab}$ & $3.09 \mathrm{BCDa}$ & $3.38 \mathrm{CDa}$ \\
$\mathrm{S}_{5}$ & - & - & - & - & - & - \\
$\mathrm{S}_{6}$ & $1.71 \mathrm{ABd}$ & $2.40 \mathrm{Ac}$ & $3.17 \mathrm{Ab}$ & $4.04 \mathrm{Aa}$ & $4.56 \mathrm{Aa}$ & $4.53 \mathrm{ABa}$ \\
$\mathrm{S}_{7}$ & $1.81 \mathrm{ABd}$ & $2.07 \mathrm{ABcd}$ & $2.20 \mathrm{Bbcd}$ & $2.58 \mathrm{BCabc}$ & $2.78 \mathrm{DEab}$ & $2.95 \mathrm{DEa}$ \\
$\mathrm{S}_{8}$ & $1.51 \mathrm{ABd}$ & $1.78 \mathrm{ABcd}$ & $2.36 \mathrm{ABbc}$ & $2.57 \mathrm{BCb}$ & $2.85 \mathrm{CDEab}$ & $3.47 \mathrm{CDa}$ \\
$\mathrm{S}_{9}$ & $1.99 \mathrm{ABd}$ & $2.12 \mathrm{ABd}$ & $2.83 \mathrm{Abc}$ & $3.38 \mathrm{ABbc}$ & $3.52 \mathrm{BCb}$ & $4.61 \mathrm{Aa}$ \\
$\mathrm{S}_{10}$ & $1.66 \mathrm{ABc}$ & $1.98 \mathrm{ABc}$ & $2.81 \mathrm{ABb}$ & $3.25 \mathrm{ABab}$ & $3.64 \mathrm{Ba}$ & $3.84 \mathrm{ABa}$ \\
\hline Mean & 1.78 & 2.01 & 2.53 & 2.90 & 3.14 & 3.50 \\
\hline
\end{tabular}

Coefficient of variation: $12.97 \%$.

Means followed by horizontally same letter and vertically capital do not differ statistically by Tukey test at $5 \%$ probability. Where: $S_{1} .100 \% P ; S_{2} .70 \% P+30 \%$ DLR; $S_{3} .60 \% P+20 \%$ SE + 20\% DLR; $S_{4} .60 \% P+30 \%$ SE + 10\% BL; $S_{5} .60 \% P+40 \%$ SE; S $.50 \% P$ $+20 \%$ SE + 30\% EB; $S_{7}-50 \%$ P + 20\% SE + 20\% EB + 10\% DLR; S $-50 \%$ P + 30\% SE + 10\% DLR + 10\% BL; S $-50 \% P+20 \%$ CRH $+30 \% \mathrm{~EB} ; \mathrm{S}_{10}-50 \% \mathrm{P}+20 \% \mathrm{CRH}+20 \% \mathrm{~EB}+10 \% \mathrm{DLR}$. Where $\mathrm{P}=$ Plantmax $\mathrm{B}$; DLR = decomposed leaf residue, result of urban pruning; $\mathrm{SE}=$ sawdust; $\mathrm{BL}=$ broiler litter; $\mathrm{BM}=$ bovine manure; $\mathrm{CAC}=$ carbonized rice husk.

The possible cause for no seedling emergence registered to $S_{5}\left(60 \%\right.$ Plantmax ${ }^{\circledR}+40 \%$ sawdust $)$ would be the lowest proportion of micro pores of this substrate, promoted by the presence of the largest number of thin particles, as recorded by Ferraz et al. (2005), thus favoring the reduction of aeration and consequently germination. Smiderle \& Minami (2001) report that the substrate should provide sufficient water retention to allow germination and when saturated, it should maintain proper amounts of pore space to facilitate the supply of oxygen, essential to germination process and root development.

Seedlings produced in $\mathrm{S}_{6}, \mathrm{~S}_{9}$ and $\mathrm{S}_{10}$ substrates, which contained in its formulation bovine manure, showed the highest values for root dry mass, 0.29, 0.21 and $0.25 \mathrm{~g}$ respectively, did not differ significantly from each other (Table 4).

Despite being considered the best parameter to determine root growth of seedlings and consequently, to promote the development in field (Carneiro,
1995), root dry mass should not be the only morphological parameter to express the quality of seedlings (Fonseca, et al. 2002). Similarly, also for the shoot dry mass, the substrates $\mathrm{S}_{6}$ and $\mathrm{S}_{9}$ had the highest means with 0.58 and $0.47 \mathrm{~g}$, respectively, not statistically different from each other. Lourenço et al. (2000) also showed favoritism to SDM and RDM in mate seedlings produced in substrates containing bovine manure, as $\mathrm{S}_{6}$ and $\mathrm{S}_{9}$.

For RDM/SDM ratio in $C$. vernalis seedlings, the highest means were found in $S_{3}(1.49)$, significantly differing from the other substrates (Table 4). Even considering that a higher RDM/SDM ratio results in better quality seedlings, it is noteworthy that no feature should be observed in isolation (Sâmor et al., 2002), as occurred in this case, where seedlings of $C$. vernalis with the highest RDM/SDM ratio accounted for lower results for dry mass of root and shoot.

The best results for leaf area were recorded in $\mathrm{S}_{6}$ and $\mathrm{S}_{9}$ (347.7 and $283.0 \mathrm{~mm}^{2}$, respectively) which 
did not differ significantly from each other (Table 4). In this case, seedlings produced in these substrates may have higher growth, which could have already observed in relation to RDM and SDM, where greater leaf area represents increased photosynthetic rate and thus, energy supply for growth and development of seedlings (Grave et al., 2007).

Table 4 - Root dry mass (RDM), shoot dry mass (SDM), the ratio between root dry mass and shoot dry mass (RDM/SDM) and leaf area obtained for seedlings of Cupania vernalis cultivated in different substrates, at 210 days after sowing.

\begin{tabular}{|c|c|c|c|c|}
\hline Substrates & $\mathrm{RDM}(\mathrm{g})$ & $\operatorname{SDM}(g)$ & RDM/SDM & $\begin{array}{l}\text { Leaf area } \\
\quad\left(\mathrm{mm}^{2}\right)\end{array}$ \\
\hline $\mathrm{S}_{1-100 \% \mathrm{P}}$ & $0.10 \mathrm{~d}$ & $0.08 \mathrm{de}$ & $1.23 \mathrm{~b}$ & $31.0 \mathrm{e}$ \\
\hline$S_{2}-70 \% P+30 \%$ DLR & $0.20 \mathrm{bc}$ & $0.34 \mathrm{bc}$ & $0.58 \mathrm{c}$ & $193.8 \mathrm{c}$ \\
\hline$S_{3}-60 \% P+20 \%$ SE $+20 \%$ DLR & $0.10 \mathrm{~d}$ & $0.07 \mathrm{e}$ & $1.49 \mathrm{a}$ & $24.3 \mathrm{e}$ \\
\hline$S_{4}-60 \% P+30 \% S E+10 \% B L$ & $0.14 \mathrm{~cd}$ & $0.22 \mathrm{~cd}$ & $0.63 \mathrm{c}$ & $114.6 \mathrm{~d}$ \\
\hline$S_{5}-60 \% P+40 \%$ SE & - & - & - & - \\
\hline$S_{6}-50 \% P+20 \% S E+30 \% E B$ & $0.29 \mathrm{a}$ & $0.58 \mathrm{a}$ & $0.65 \mathrm{c}$ & $347.7 \mathrm{a}$ \\
\hline$S_{7}-50 \% P+20 \% S E+20 \% E B+10 \%$ DLR & $0.08 \mathrm{~d}$ & $0.13 \mathrm{de}$ & $0.61 \mathrm{c}$ & $63.8 \mathrm{de}$ \\
\hline $\mathrm{S}_{8}-50 \% \mathrm{P}+30 \% \mathrm{SE}+10 \% \mathrm{DLR}+10 \% \mathrm{BL}$ & $0.11 \mathrm{~d}$ & $0.21 \mathrm{de}$ & $0.52 \mathrm{c}$ & $103.7 \mathrm{~d}$ \\
\hline$S_{9}-50 \% P+20 \% \mathrm{CRH}+30 \% \mathrm{~EB}$ & $0.21 \mathrm{abc}$ & $0.47 \mathrm{ab}$ & $0.45 \mathrm{c}$ & $283.0 \mathrm{ab}$ \\
\hline$S_{10}-50 \% P+20 \% C R H+20 \% E B+10 \%$ DLR & $0.25 \mathrm{ab}$ & $0.39 \mathrm{~b}$ & $0.68 \mathrm{c}$ & $220.4 \mathrm{bc}$ \\
\hline Mean & 0.16 & 0.28 & 0.73 & 153.50 \\
\hline Coefficient of variation (\%) & 27.47 & 26.82 & 27.05 & 20.00 \\
\hline
\end{tabular}
carbonized rice husk.

For water retention capacity variable, there was no significant difference between the tested substrates, with values ranging from $39.76 \%$ to $60.40 \%$ (Table 5). Substrates with carbonized rice husk in its constitution are among the substrates with the lowest values for water retention Gonçalves \& Poggiani (1996) reported that substrates that contain materials normally incinerated retain less water, such as carbonized rice husk, increasing when present the drainage of the substrates (Almeida, 2005).

Table 5 - Water retention capacity (WRC) and total porosity for different substrates tested in the growth of Cupania vernalis seedlings.

\begin{tabular}{lcc}
\hline Substrate & WRC (\% v/v) & Total porosity (\%) \\
\hline$S_{1}-100 \% \mathrm{P}$ & $60.40 \mathrm{a}$ & $65.69 \mathrm{a}$ \\
$\mathrm{S}_{2}-70 \% \mathrm{P}+30 \% \mathrm{DLR}$ & $54.25 \mathrm{a}$ & $63.03 \mathrm{ab}$ \\
$\mathrm{S}_{3}-60 \% \mathrm{P}+20 \% \mathrm{SE}+20 \% \mathrm{DLR}$ & $49.00 \mathrm{a}$ & $61.63 \mathrm{ab}$ \\
$\mathrm{S}_{4}-60 \% \mathrm{P}+30 \% \mathrm{SE}+10 \% \mathrm{BL}$ & $51.34 \mathrm{a}$ & $58.73 \mathrm{ab}$ \\
$\mathrm{S}_{5}-60 \% \mathrm{P}+40 \% \mathrm{SE}$ & $50.89 \mathrm{a}$ & $59.94 \mathrm{ab}$ \\
$\mathrm{S}_{6}-50 \% \mathrm{P}+20 \% \mathrm{SE}+30 \% \mathrm{~EB}$ & $51.90 \mathrm{a}$ & $59.62 \mathrm{ab}$ \\
$\mathrm{S}_{7}-50 \% \mathrm{P}+20 \% \mathrm{SE}+20 \% \mathrm{~EB}+10 \% \mathrm{DLR}$ & $54.86 \mathrm{abc}$ \\
$\mathrm{S}_{8}-50 \% \mathrm{P}+30 \% \mathrm{SE}+10 \% \mathrm{DLR}+10 \% \mathrm{BL}$ & $51.68 \mathrm{bc}$ \\
$\mathrm{S}_{9}-50 \% \mathrm{P}+20 \% \mathrm{CRH}+30 \% \mathrm{~EB}$ & $42.59 \mathrm{a}$ & $43.76 \mathrm{c}$ \\
$\mathrm{S}_{10}-50 \% \mathrm{P}+20 \% \mathrm{CRH}+20 \% \mathrm{~EB}+10 \% \mathrm{DLR}$ & $39.76 \mathrm{a}$ & $51.65 \mathrm{bc}$ \\
\hline Mean & $43.88 \mathrm{a}$ & 57.06 \\
\hline Coefficient of variation $\%)$ & 48.86 & 6.36 \\
\hline
\end{tabular}

Means followed by horizontally same letter and vertically capital do not differ statistically by Tukey test at $5 \%$ probability. Where $\mathrm{P}=$ Plantmax $\AA^{\circ} ; \mathrm{DLR}=$ decomposed leaf residue, result of urban pruning; $\mathrm{SE}=$ sawdust; $\mathrm{BL}=$ broiler litter; $\mathrm{BM}=$ bovine manure; $\mathrm{CAC}=$ carbonized rice husk.

According to the data shown in Table 5 for total porosity, the $S_{1}$ substrate $(65.69 \%)$, significantly differed from only $S_{8}, S_{9}$ and $S_{10}(51.68 ; 43.76$ and $51.65 \%$ respectively). Possibly, the highest value of total porosity to $S_{1}$, could be representing higher amount of micropores, since substrates formulated with a higher proportion of porous materials would present higher porosity (Rondon Neto \& Ramos 2010), as in the case of the other substrates.

The values for total porosity of tested substrates ranged from $65.69 \%$ to $43.76 \%$ (Table 5 ), in a range below recommended, which it would be 
around 75 and $90 \%$, for better aeration, water infiltration and drainage (Gonçalves \& Poggiani, 1996; Almeida, 2005). However, the ideal substrate choice should be according to the need of aeration or water for the cultivated species, in addition to irrigation management to be adopted (Ferraz et al., 2005).

Table 6 - Nutritional content for different substrates at experiment implantation with Cupania vernalis.

\begin{tabular}{|c|c|c|c|c|c|c|c|c|c|}
\hline \multirow{2}{*}{ Substrate } & $\mathrm{N}$ & $\mathrm{P}$ & $\mathrm{K}$ & $\mathrm{Ca}$ & $\mathrm{Mg}$ & $\mathrm{Cu}$ & $\mathrm{Zn}$ & $\mathrm{Mn}$ & $\mathrm{Fe}$ \\
\hline & \multicolumn{5}{|c|}{ - } & \multicolumn{4}{|c|}{----------- $\left(\mathrm{mg} \mathrm{kg}^{-1}\right)$------------ } \\
\hline $\mathrm{S}_{1}$ & 4.38 & 3.36 & 6.60 & 13.60 & 7.00 & 34.0 & 50.0 & 360.0 & 1896.0 \\
\hline $\mathrm{S}_{2}$ & 20.13 & 1.33 & 5.05 & 10.50 & 6.15 & 81.0 & 73.0 & 512.0 & 1989.0 \\
\hline $\mathrm{S}_{3}$ & 8.75 & 1.05 & 5.15 & 8.25 & 5.70 & 104.0 & 79.0 & 480.0 & 2013.0 \\
\hline$S_{4}$ & 15.75 & 3.01 & 4.85 & 9.80 & 5.85 & 122.0 & 196.0 & 439.0 & 1952.0 \\
\hline $\mathrm{S}_{5}$ & 14.88 & 1.01 & 4.75 & 8.60 & 6.10 & 59.0 & 58.0 & 362.0 & 1950.0 \\
\hline $\mathrm{S}_{6}$ & 5.25 & 5.78 & 5.65 & 19.15 & 6.30 & 318.0 & 301.0 & 590.0 & 1976.0 \\
\hline$S_{7}$ & 7.88 & 3.70 & 5.65 & 13.45 & 5.95 & 189.0 & 221.0 & 517.0 & 1972.0 \\
\hline $\mathrm{S}_{8}$ & 7.00 & 6.21 & 5.30 & 17.15 & 6.15 & 233.0 & 285.0 & 680.0 & 1897.0 \\
\hline $\mathrm{S}_{9}$ & 5.25 & 6.18 & 5.55 & 16.55 & 6.20 & 305.0 & 296.0 & 618.0 & 1967.0 \\
\hline$S_{10}$ & 8.75 & 5.16 & 5.35 & 17.15 & 5.15 & 205.0 & 259.0 & 574.0 & 1980.0 \\
\hline
\end{tabular}

$\mathrm{S}_{1}=100 \% \mathrm{P}$ (witness); $\mathrm{S}_{2}=70 \% \mathrm{P}+30 \%$ DLR; $\mathrm{S}_{3}=60 \% \mathrm{P}+20 \% \mathrm{SE}+20 \%$ DLR; $\mathrm{S}_{4}=60 \% \mathrm{P}+30 \% \mathrm{SE}+10 \% \mathrm{BL} ; \mathrm{S}_{5}=60 \% \mathrm{P}+40 \%$ SE; $S_{6}=50 \% P+20 \%$ SE $+30 \%$ EB; $S_{7}=50 \% P+20 \%$ SE $+20 \%$ EB $+10 \%$ DLR; $\mathrm{S}_{8}=50 \% \mathrm{P}+30 \% \mathrm{SE}+10 \% \mathrm{DLR}+10 \% \mathrm{BL} ;$ $\mathrm{S}_{9}=50 \% \mathrm{P}+20 \% \mathrm{CRH}+30 \% \mathrm{~EB} ; \mathrm{S}_{10}=50 \% \mathrm{P}+20 \mathrm{CRH}+20 \% \mathrm{~EB}+10 \%$ DLR. Where P = Plantmax $\mathrm{B} ; \mathrm{DLR}=$ decomposed leaf residue, result of urban pruning; $\mathrm{SE}=$ sawdust; $\mathrm{BL}=$ broiler litter; $\mathrm{BM}=$ bovine manure; $\mathrm{CAC}=$ carbonized rice husk.

When total nutrient contents for tested substrates were evaluated (Table 6), it is clear that there were no significant differences for the quantification of each element in the different substrates. The $\mathrm{S}_{2}, \mathrm{~S}_{4}$ and $\mathrm{S}_{5}$ substrates had the highest levels for $\mathrm{N}$, an important element in the synthesis of chlorophyll, enzymes, proteins, nucleic acids (Epstein \& Bloom, 2006) and with positive effect on seedling growth (Braga et al., 1995; Silva \& Muniz, 1995).

The $P$ contents were lower in $S_{2}, S_{3}$ and $S_{5}$, substrates which have in its composition a greater proportion of decomposed leaf residue. Barrata Junior (2007) also had lower contents of P for the compound of urban pruning compared to other residues such as sugarcane bagasse.

The lack of $\mathrm{P}$ in the production of cedar (Cedrela fissilis) caused reduction in the height of seedlings (Silva \& Muniz, 1995), reduction that also occurred in Acacia maginum seedlings on nutrient omission tests (Braga et al., 1995), as seen in the seedling of C. vernalis produced in S3 $\left(60 \%\right.$ Plantmax $^{\circledR}+20 \%+$ $+20 \%$ sawdust $+20 \%$ of decomposed leaf residue), which have lower contents of $P$ (Table 6 ) and the lowest mean for height (Table 3).

Regarding micronutrients, it highlights the lower contents of $\mathrm{Cu}$ and $\mathrm{Zn}$ to $\mathrm{S}_{1}$ (Table 6). Although with great variation, it have already been recorded for the (Epstein \& Bloom, 2006), some characteristics observed in C. vernalis seedlings, grown under $100 \%$ of Plantmax ${ }^{\circledast}\left(\mathrm{S}_{1}\right)$.

In Table 7, it is observed the total nutritional content of $C$. vernalis seedlings and its respective substrates after the end of the experiment. As already mentioned, $\mathrm{N}$ has great importance in the development of seedlings, as seen in those produced in $\mathrm{S}_{6}$, which showed the highest contents of $\mathrm{N}$ and the best growth as outlined in the results for diameter and height of seedlings (Table 2 and 3 ) while lower contents were for $\mathrm{S}_{1}, \mathrm{~S}_{2}$ and $\mathrm{S}_{3}$.

Even after use by plants and the portion that it was certainly leached, tested mixtures also showed significant nutritional value (Table 7), demonstrating the ability of mineralization of organic forms in the mixture, and the use possibility by plants for longer, if necessary.

The high contents of copper on substrates as $\mathrm{S}_{4}$, $S_{6}$ and $S_{8}$, are probably due to the possibility of this mineral is adsorbed to organic colloids, whereas the lower iron content registered to $S_{1}$ may be explained by its composition, since in other substrates, the organic matter could still be in decomposition and thus providing iron (Malavolta, 2006).

Another fact that could justify the high contents of nutrients in substrates at the end of experiment was the constant supply of nutrients, available in irrigation water, which came from the Itaipu Lake reservoir. Wosiack (2005) have reported high concentrations of phosphorus and nitrogen in the Itaipu Reservoir, in Entre Rios do Oeste.

When some physical and chemical characteristics of the tested substrates were analyzed, it is clear that the difference recorded for growth of $C$. vernalis seedlings, it was probably due to variations in physical characteristics instead of the chemical. Maeda et al. (2007) consider that in a substrate, the physical characteristics are more important than chemical characteristics, since the physical is not easily modified.

By evaluating morphological parameters in C. vernalis seedlings, it was observed that seedlings in $\mathrm{S}_{6}, \mathrm{~S}_{9}$ and $\mathrm{S}_{10}$ showed the best results in most of tested variables. These substrates were consisted of $50 \%$ Plantmax $\AA+20 \%$ sawdust $+30 \%$ manure $\left(\mathrm{S}_{6}\right), 50 \%$ Plantmax $\AA+30 \%$ bovine manure $+20 \%$ carbonized rice husk $\left(\mathrm{S}_{9}\right)$ and 50\% Plantmax ${ }^{\circledR}+20 \%$ carbonized 
rice husk $+20 \%$ bovine manure $+10 \%$ decomposed leaf residue $\left(S_{10}\right)$. With the use of these substrates, cost reduction would be possible, as estimated the cost of $1 \mathrm{~m}^{3}$ of $\mathrm{S}_{6}$ or $\mathrm{S}_{9}$ would be $\mathrm{R} \$ 41.68$ and $\mathrm{S}_{10} \mathrm{R} \$$ 41.43 , while only using the commercial substrate $R \$$ 82.08 (Table 1).

Table 7 - Total nutrient contents of Cupania vernalis seedlings and the different substrates at the end of the experiment at 210 days after sowing.

\begin{tabular}{|c|c|c|c|c|c|c|c|c|c|}
\hline \multirow{2}{*}{ Seedlings } & $\mathrm{N}$ & $\mathrm{P}$ & $\mathrm{K}$ & $\mathrm{Ca}$ & $\mathrm{Mg}$ & $\mathrm{Cu}$ & $\mathrm{Zn}$ & $\mathrm{Mn}$ & $\mathrm{Fe}$ \\
\hline & \multicolumn{5}{|c|}{ - $\left(\mathrm{g} \mathrm{kg}^{-1}\right)$ - } & \multicolumn{4}{|c|}{ - } \\
\hline $\mathrm{S}_{1}$ & 7.0 & 1.5 & 14.6 & 9.3 & 3.3 & 16.0 & 178.0 & 98.0 & 6200.0 \\
\hline $\mathrm{S}_{2}$ & 8.8 & 1.3 & 14.4 & 7.7 & 3.2 & 17.0 & 153.0 & 130.0 & 6440.0 \\
\hline $\mathrm{S}_{3}$ & 6.1 & 1.2 & 12.9 & 7.8 & 3.7 & 19.0 & 87.0 & 103.0 & 6340.0 \\
\hline $\mathrm{S}_{4}$ & 12.3 & 1.7 & 15.2 & 11.7 & 4.9 & 27.0 & 117.0 & 107.0 & 3730.0 \\
\hline $\mathrm{S}_{5}$ & & - & & - & - & 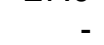 & & & . \\
\hline $\mathrm{S}_{6}$ & 21.9 & 1.5 & 14.8 & 10.0 & 5.2 & 20.0 & 97.0 & 70.0 & 2570.0 \\
\hline $\mathrm{S}_{7}$ & 11.4 & 1.6 & 15.5 & 8.3 & 3.8 & 15.0 & 77.0 & 77.0 & 3590.0 \\
\hline $\mathrm{S}_{8}$ & 10.5 & 1.5 & 16.2 & 12.8 & 4.3 & 22.0 & 92.0 & 105.0 & 4870.0 \\
\hline $\mathrm{S}_{9}$ & 14.9 & 1.3 & 16.4 & 19.0 & 4.7 & 9.0 & 90.0 & 71.0 & 3250.0 \\
\hline$S_{10}$ & 11.4 & 1.2 & 15.6 & 19.9 & 4.4 & 11.0 & 76.0 & 73.0 & 3710.0 \\
\hline \multicolumn{10}{|c|}{$\begin{array}{l}\text { Substrates at } \\
\text { assessment }\end{array}$} \\
\hline $\mathrm{S}_{1}$ & 4.4 & 2.2 & 4.6 & 18.5 & 10.2 & 48.0 & 316.0 & 203.0 & 12700.0 \\
\hline $\mathrm{S}_{2}$ & 1.8 & 1.6 & 12.2 & 21.9 & 10.0 & 125.0 & 275.0 & 420.0 & 15790.0 \\
\hline $\mathrm{S}_{3}$ & 6.1 & 2.3 & 4.7 & 17.4 & 10.6 & 83.0 & 93.0 & 404.0 & 15650.0 \\
\hline $\mathrm{S}_{4}$ & 7.0 & 4.5 & 4.1 & 26.7 & 11.6 & 184.0 & 300.0 & 441.0 & 14740.0 \\
\hline $\mathrm{S}_{5}$ & - & - & - & - & - & - & - & - & - \\
\hline $\mathrm{S}_{6}$ & 8.8 & 6.5 & 2.8 & 35.5 & 8.6 & 199.0 & 275.0 & 603.0 & 15400.0 \\
\hline $\mathrm{S}_{7}$ & 9.6 & 3.5 & 3.2 & 17.9 & 7.2 & 87.0 & 189.0 & 433.0 & 15550.0 \\
\hline $\mathrm{S}_{8}$ & 11.4 & 3.8 & 2.9 & 23.7 & 7.6 & 193.0 & 261.0 & 482.0 & 15710.0 \\
\hline $\mathrm{S}_{9}$ & 7.9 & 4.2 & 3.7 & 18.2 & 8.6 & 84.0 & 214.0 & 460.0 & 15450.0 \\
\hline$S_{10}$ & 7.0 & 3.2 & 3.0 & 16.6 & 5.6 & 89.0 & 183.0 & 410.0 & 15550.0 \\
\hline
\end{tabular}

$\mathrm{S}_{1}=100 \% \mathrm{P}$ (witness); $\mathrm{S}_{2}=70 \% \mathrm{P}+30 \% \mathrm{DLR} ; \mathrm{S}_{3}=60 \% \mathrm{P}+20 \% \mathrm{SE}+20 \% \mathrm{DRL} ; \mathrm{S}_{4}=60 \% \mathrm{P}+30 \% \mathrm{SE}+10 \% \mathrm{BL} ; \mathrm{S}_{5}=60 \% \mathrm{P}+40 \% \mathrm{SE}$ $\mathrm{S}_{6}=50 \% \mathrm{P}+20 \% \mathrm{SE}+30 \% \mathrm{~EB} ; \mathrm{S}_{7}=50 \% \mathrm{P}+20 \% \mathrm{SE}+20 \% \mathrm{~EB}+10 \% \mathrm{DLR} ; \mathrm{S}_{8}=50 \% \mathrm{P}+30 \% \mathrm{SE}+10 \% \mathrm{DLR}+10 \% \mathrm{BL} ; \mathrm{S}=50 \% \mathrm{P}$ $+20 \% \mathrm{CRH}+30 \% \mathrm{~EB} ; \mathrm{S}_{10}=50 \% \mathrm{P}+20 \mathrm{CRH}+20 \% \mathrm{~EB}+10 \%$ DLR. Where P = Plantmax®; DLR = decomposed leaf residue, result of urban pruning; $\mathrm{SE}=$ sawdust; $\mathrm{BL}=$ broiler litter; $\mathrm{BM}=$ bovine manure; $\mathrm{CAC}=$ carbonized rice husk.

Another fact that could justify the high contents of nutrients in substrates at the end of experiment was the constant supply of nutrients, available in irrigation water, which came from the Itaipu Lake reservoir. Wosiack (2005) have reported high concentrations of phosphorus and nitrogen in the Itaipu Reservoir, in Entre Rios do Oeste.

When some physical and chemical characteristics of the tested substrates were analyzed, it is clear that the difference recorded for growth of $C$. vernalis seedlings, it was probably due to variations in physical characteristics instead of the chemical. Maeda et al. (2007) consider that in a substrate, the physical characteristics are more important than chemical characteristics, since the physical is not easily modified.

By evaluating morphological parameters in $C$. vernalis seedlings, it was observed that seedlings in $\mathrm{S}_{6}$, $S_{9}$ and $S_{10}$ showed the best results in most of tested variables. These substrates were consisted of $50 \%$ Plantmax ${ }^{\circledR}+20 \%$ sawdust $+30 \%$ manure $\left(\mathrm{S}_{6}\right), 50 \%$ Plantmax ${ }^{\circledR}+30 \%$ bovine manure $+20 \%$ carbonized rice husk $\left(\mathrm{S}_{9}\right)$ and $50 \%$ Plantmax ${ }^{\circledR}+20 \%$ carbonized rice husk $+20 \%$ bovine manure $+10 \%$ decomposed leaf residue $\left(\mathrm{S}_{10}\right)$. With the use of these substrates, cost reduction would be possible, as estimated the cost of $1 \mathrm{~m}^{3}$ of $S_{6}$ or $S_{9}$ would be $R \$ 41.68$ and $S_{10} R \$$
41.43 , while only using the commercial substrate $R \$$ 82.08 (Table 1).

\section{Conclusions}

For the production of Cupania vernalis seedlings, in the presented conditions, it is suggested the use of the substrate consisted of $50 \%$ Plantmax $^{\circledR}+$ $+20 \%$ sawdust $+30 \%$ bovine manure $\left(\mathrm{S}_{6}\right)$, the substrate consisted of $50 \%$ Plantmax ${ }^{\circledR}+30 \%$ bovine manure $+20 \%$ carbonized rice husk $\left(\mathrm{S}_{9}\right)$ and $50 \%$ Plantmax ${ }^{\circledR}+20$ carbonized rice husk $+20 \%$ bovine manure $+10 \%$ decomposed leaf residue $\left(\mathrm{S}_{10}\right)$. There was a gradual increase over time for the growth of seedlings, except those produced in $S_{1}(100 \%$ Plantmax) and $\mathrm{S}_{3}\left(60 \%\right.$ Plantmax $^{\circledR}+20 \%$ sawdust + $+20 \%$ decomposed leaf residue).

\section{References}

Almeida LS (2005) Avaliação morfológica de mudas de Allophylus edulis (A, St.- Hil., A. Juss. \& Cambess.) Radl. (Vacum) e Schinus terebinthifoliu Raddi (aroeira) produzidas em diferentes substratos. 96 p. Universidade Federal do Paraná (Dissertação Mestrado em Engenharia Florestal). 
Backes P, Irgang B (2002) Árvores do Sul: guia de identificação e interesse ecológico. Curitiba: Souza Cruz. 325p.

Barrata Junior AP (2007) Utilização do composto de resíduo da poda da arborização urbana em substratos para a produção de mudas. 53p. Universidade Federal Rural do Rio de Janeiro (Dissertação Mestrado em Ciências, Conservação da Natureza).

Benincasa MMP (1988) Análise de crescimento de plantas: noções básicas. Jaboticabal: FCAV-UNESP. $41 \mathrm{p}$.

Bortolini MF, Koehler HS, Zuffellato-Ribas KC, Fortes AMT (2012) Crescimento de mudas de Gleditschia amorphoides Taub. produzidas em diferentes substratos. Ciência Florestal, 22(1):35-46.

Braga FA, Vale FR, Ventorim N, Aubert E, Lopes GA (1995) Exigências nutricionais de quatro espécies florestais. Revista Árvore, 19(3):18-31.

Brasil (2006) Instrução Normativa $n^{\circ} 46$ de 12/09/2006. (Aprova os Métodos Analíticos Oficiais para Análise de Substratos e Condicionadores de Solos, na forma do Anexo à presente Instrução Normativa). Diário Oficial da União, n 177 de 14/09/2006.

Bremner JM (1965) Total nitrogen. In: Black CA (Ed). Methods of soil analysis Part 2- Chemical and Microbiological Properties. Madison: American Society of Agronomy, p.1149-1178.

Carneiro JGA (1995) Produção e controle de qualidade de mudas florestais. Curitiba: UFPR/FUPEF, $451 \mathrm{p}$.

Carvalho PER (2000) Produção de mudas de espécies nativas por sementes e a implantação de povoamentos. In: Galvão APM. Reflorestamento de propriedades rurais para fins produtivos e ambientais: um guia para ações municipais e regionais. Colombo: Embrapa Floresta, p.151-174.

Costa E, Silva PNL, Jorge MHA, Ferreira FA (2012) Guavira emergence and seedling production with substrates containing organic compost and soil under different screen environments. Revista Brasileira de Fruticultura, 34(4):1289-1293.

Cunha AM, Cunha GM, Sarmento RA, Cunha GM, AmaraL JFT (2006) Efeito de diferentes substratos sobre o desenvolvimento de mudas de Acacia sp. Revista Árvore, 3(2):207-214.

Epstein E, Bloom A (2006) Nutrição mineral de plantas: princípios e perspectivas. Londrina: editora Planta. 403p.
Ferraz MV, Centurion JF, Beutler AN (2005) Caracterização física e química de alguns substratos comerciais. Acta Scientiarum, 27(2):209-214.

Fowler JAP (2000) Superação de dormência e armazenamento de sementes de espécies florestais. In: Galvão APM. Reflorestamento de propriedades rurais para fins produtivos e ambientais: um guia para ações municipais e regionais. Colombo: Embrapa Floresta, p.77-100.

Fonseca EP, Valéri SV, Miglioranza E, Fonseca NAN, Couto L (2002) Padrão de qualidade de mudas de Trema micrantha (L.) Blume, produzidas sob diferentes períodos de sombreamento. Revista Árvore, 26(4):515-523.

Gonçalves JLM, Poggiani F (1996) Substratos para produção de mudas florestais. In: CONGRESSO LATINO AMERICANO DE CIÊNCIA DO SOLO, 13., Águas de Lindóia, 1996. Resumos. Piracicaba, Sociedade Latino Americana de Ciência do Solo, CD-Rom.

Grave F, Franco ETH, Pacheco JP, Santos SR (2007) Crescimento de plantas jovens de açoita-cavalo em quatro diferentes substratos. Ciência Florestal, 17(4):289-298.

Guimarães Junior PR, Cogni R (2002) Seed cleaning of Cupania vernalis (Sapindaceae) by ants: edge effect in a highland forest in south-east Brazil. Journal of Tropical Ecology, 18:303-307.

Johnson CM, Ulrich A (1959) Analytical methods for use in plant analysis. Raleigh: North Carolina State University, p. 32-33. (California Agriculture Experimental Station Bulletin, 766).

José AC, Davide AC, Oliveira SL (2005) Produção de mudas de aroeira (Schinus terebinthifolius Raddi) para a recuperação de áreas degradadas pela mineração de bauxita. Cerne, 11(2):187-196.

Lorenzi H (2000) Árvores brasileiras. Manual de identificação e cultivo de plantas arbóreas nativas do Brasil. Nova Odessa. 368p.

Lourenço RS, Medrado MJS, Fowler JAP, Mosele SH (2000) Influência do substrato no desenvolvimento de mudas de erva-mate (llex paraguariensis St. Hil.). Perspectiva, 24(88):81-99.

Maeda S, Dedecek RA, Agostini RB, Andrade GC, Silva HD (2007) Caracterização de substratos para a produção de mudas de espécies florestais elaborados a partir de resíduos orgânicos. Pesquisa Florestal Brasileira, (54):97-104.

Malavolta E (2006) Manual de nutrição mineral de plantas. São Paulo: Editora Agronômica Ceres, 638p. 
Oliveira RB, Lima JSS, Souza CAM, Silva SA, Martins Filho S (2008) Produção de mudas de essências florestais em diferentes substratos e acompanhamento do desenvolvimento em campo. Ciência e Agrotecnológica, 32(1):122-128.

Rondon Neto RM, Ramos CB (2010) Avaliação das características físicas de substratos formulados com resíduos orgânicos para a produção de mudas florestais em tubetes. Pesquisa aplicada \& Agrotecnologia, 3(2):117-122.

Silva MAG, Muniz AS (1995) Exigências nutricionais de mudas de cedro (Cedrela fissilis Velloso) em solução nutritiva. Revista Árvore, 19(3):415-125.

Silveira EB, Rodrigues VJLB, Gomes AMA, Mariano RLR, Mesquita JCP (2002) Pó de coco como substrato para a produção de mudas de tomateiro. Horticultura Brasileira, 20(2):211-216.

Smiderle OS, Minami K (2001) Emergência e vigor de plântulas de goiabeira em diferentes substratos. Revista Científica Rural, 6(1):38-45.
Souza CAM, Oliveria RB, Martins Filho S, Lima JSS (2006) Crescimento em campo de espécies florestais em diferentes condições de adubação. Ciência Florestal,16(3):243-249.

Souza VC, Andrade LA, Bruno RLA, Cunha AO, Souza AP (2005) Produção de mudas de ipê-amarelo (Tabebuia serratifolia (Vahl.) Nich.) em diferentes substratos e tamanhos de recipientes. Agropecuária Técnica, 26(2):98-108.

Toledo ARM (1992) Efeito de substratos na formação de mudas de laranjeira (Citrus sinensis (L.) OSBECK cv. "Pêra Rio') em vaso. Universidade Federal de Lavras (Dissertação Mestrado em Fitotecnia), 96p.

Wendling I, Gatto A, Paiva HN, Gonçalves W (2002) Substratos, Adubação e Irrigação na Produção de Mudas. Viçosa: Aprenda Fácil Editora,145p.

Wosiack AC (2005) Dinâmica da comunidade de cianobactérias da praia Artificial de Entre Rios do Oeste, reservatório de Itaipu, PR. 75p. Universidade Federal do Paraná (Dissertação Mestrado em Botânica). 